\title{
Escritos políticos de Francisco Julião no processo de redemocratização do Brasil (1981-1985)
}

\author{
Pablo Francisco de Andrade Porfirio*
}

\section{RESUMO}

Francisco Juliáo ficou conhecido, nacional e internacionalmente, pela sua ação frente às Ligas Camponesas, em Pernambuco, entre meados de 1950 e o golpe civil-militar de 1964. Advogado dos camponeses, deputado estadual e federal pelo Partido Socialista Brasileiro (PSB) foi preso em junho de 1964 e conseguiu asilo político na embaixada do México, no Rio de Janeiro, em outubro do ano seguinte. Na historiografia, esse é o período mais conhecido de sua trajetória política. Este artigo, contudo, estuda as suas açóes no momento pós-exílio, a partir de 1979, com destaque para o período da redemocratização do Brasil e, mais especificamente, o movimento de Diretas Já. Procura-se analisar como, nesse período, Francisco Julião operou com o seu passado de líder das Ligas Camponesas, colocando sua memória em diálogo com a escrita sobre o tempo presente, ou seja, o processo de redemocratização do país.

Palavras-chave: Política; memória; Diretas Já.

\section{ABSTRACT}

Francisco Julião became known national and internationally for his actions as the leader of the Peasant Leagues in Pernambuco, from the mid-1950s to the civil-military coup of 1964. A lawyer for the peasants, and a,state and then federal representative for the Brazilian Socialist Party (PSB), Julião was arrested in June 1964, and got political asylum in the Mexican Embassy of Rio de Janeiro in October of the following year. In historiography, this is the best-known period of his political trajectory. This paper, however, studies his actions in exile from 1979 on, emphasizing the period of re-democratization of Brazil, and more specifically the Diretas Já movement. It seeks to analyze how Julião operated his past as a leader of the Peasant Leagues, putting his memory in dialogue with the present in his writings through the country's democratization process.

Keywords: politics; memory; Diretas Já. cação da Universidade Federal de Pernambuco (CAp-UFPE). Recife, PE, Brasil. E-mail: pabloporfirio@ hotmail.com. 


\section{Introdução}

Nascido em 16 de fevereiro de 1915, no Engenho Boa Esperança, na cidade de Bom Jardim, em Pernambuco, Francisco Juliano Arruda de Paula, ou apenas Francisco Julião, era integrante de uma família católica de senhores de engenho. Na década de 1920, iniciou seus estudos no Recife, ingressando nos anos 1930 na Faculdade de Direito, onde obteve o grau de bacharel em dezembro de 1939. Foi eleito, por duas vezes, 1954 e 1958, deputado estadual em Pernambuco pelo Partido Socialista Brasileiro. Em 1962, tornou-se deputado federal pelo mesmo partido. ${ }^{1}$

Contudo, foi como líder do movimento conhecido como Ligas Camponesas, entre 1955 e 1964, que Francisco Julião ganhou destaque tanto nacional como internacional. A mobilização desses camponeses tornou-se tema constante na imprensa e no final da década de 1950 e início dos anos 1960 diversas missóes jornalistas passaram a se dirigir ao Nordeste do Brasil, sobretudo a Pernambuco, a fim de conhecer como se organizava o movimento de camponeses que conseguira, inclusive, a desapropriação do Engenho Galileia, em 1959.² Além disso, vários jornalistas, professores, diplomatas e representantes de governos desejavam conhecer e entrevistar a pessoa identificada como o responsável por liderar essa grande mobilização de camponeses em Pernambuco, ou seja, Francisco Julião. ${ }^{3}$

Ele passou a se relacionar com outros líderes de esquerda em diversos estados e países, com destaque para Cuba, onde estabeleceu um diálogo próximo com Fidel Castro, realizando diversas viagens para aquela ilha. Começou então a defender para o Brasil os ideais de uma revolução a partir do campo, sendo por isso acusado de receber dinheiro e apoio logístico cubano para organizar uma guerrilha rural. ${ }^{4}$ Nessas circunstâncias, as açóes de Julião tornaram-se notícias na imprensa internacional, como no The New York Times e na revista Life.

Com o golpe civil-militar de março de 1964, o líder das Ligas Camponesas e entáo deputado federal socialista foi preso. Em 1965, conseguiu um habeas corpus e se exilou no México, onde passou a atuar na rede política ligada ao Partido Revolucionário Institucional (PRI), que

\footnotetext{
${ }^{1}$ SANTIAGO, Vandeck. Francisco Julião: Luta, paixão e morte de um agitador. Coleção Perfil Parlamentar Século XX. Assembleia Legislativa do Estado de Pernambuco. Recife, 2001. Sobre esses anos de formação de Francisco Julião, ver o relato detalhado de AGUIAR, Cláudio. Francisco Julião, uma biografia: o homem e a política, as ligas camponesas e a reforma agrária, exílio e ocaso. 1. ed. Rio de Janeiro: Civilização Brasileira, 2014. ${ }^{2}$ Sobre o processo de desapropriação do Engenho Galileia, ver PORFÍRIO, Pablo F. de A. Medo, Comunismo e Revolução. Pernambuco (1958-1964). Recife: Ed. da UFPE, 2009.

${ }^{3}$ Sobre algumas dessas missōes jornalísticas ver FURTADO, Celso. A fantasia desfeita. 3. edição. Rio de Janeiro: Paz e Terra, 1989, p. 109-110.

${ }_{4}^{4}$ Sobre essa questão ver ROLLEMBERG, Denise. O apoio de Cuba à luta armada no Brasil: o treinamento guerrilheiro. Rio de Janeiro: Mauad, 2001. SALES, Jean Rodrigues. A luta armada contra a ditadura militar: a esquerda brasileira e a influência da Revolução Cubana. São Paulo: Fundação Perseu Abramo, 2007.

${ }_{5}^{5}$ The New York Times. Monday, October 31, 1960. p. 1. Life, June, 1961.
} 
comandava o país há décadas. Em 1979, regressou ao Brasil beneficiado pela Lei de Anistia. Integrou-se ao Partido Democrático Trabalhista (PDT) e buscou produzir uma reinserção política, que envolveu tentativas de desconstrução, reconstrução e ressignificação das memórias existentes sobre a sua atuação no período anterior ao golpe civil-militar de 1964.

Atualmente, Francisco Julião é uma referência pouco lembrada. Náo existe um instituto que organize e divulgue seus livros e documentação. Tampouco há um memorial sobre o movimento que liderou, as Ligas Camponesas. ${ }^{6}$ Em geral, as citaçóes a ele na historiografia e na imprensa restringem-se a nomeá-lo como o líder de um movimento camponês cujos discursos, em um período de polarização política, aterrorizavam os grupos de direita e causavam problemas para os da esquerda. Em grande parte das vezes, Francisco Julião é lembrado por meio desse viés da radicalização, que teria caracterizado suas açóes nos primeiros anos da década de 1960. Entretanto, em 1979, quando regressou ao Brasil e buscou promover sua reinserção política, ele teve a possibilidade de promover deslocamentos de memória, circular em outras redes políticas e romper com a cápsula que haveria aprisionado seu passado em um determinado formato, sob uma chave crítica negativa de leitura.

Parte das referências historiográficas ${ }^{7}$ sobre ele reforça este lugar de crítica. Jorge Ferreira, no livro João Goulart: uma biografia, procura mostrar como o presidente foi atingido pela radicalização promovida por algumas pessoas e grupos sociais. Entre essas estaria o então dirigente das Ligas Camponesas, que falava "bravatas", segundo o autor, ao anunciar a existência de milhares de camponeses armados no Nordeste do Brasil. ${ }^{8}$

O historiador Thomas Skidmore já havia construído uma leitura semelhante. Sem adjetivar as açôes e os discursos de Francisco Julião, colocava-o como um dos "radicalizantes" que atuou durante o governo de Jango. Para o autor, a radicalização relacionava-se "à crença de que cada um estava em condiçóes de ganhar mais com o desmoronamento da política democrática". ${ }^{9}$ Dessa perspectiva era tomada a ação do líder das Ligas Cam-

\footnotetext{
${ }^{6}$ Refiro-me aqui especialmente ao estado de Pernambuco, onde surgiram as primeiras Ligas Camponesas e no qual Julião atuou fortemente. Na Paraíba existe um Memorial das Ligas Camponesas, localizado na cidade de Sapé, onde no início década de 1960 funcionou uma das maiores Ligas Camponesas em número de associados. A Liga de Sapé era liderada por João Pedro Teixeira, assassinado em 1962. Pode-se conhecer melhor esse memorial por meio do site http://www.ligascamponesas.org.br/.

${ }^{7}$ Há poucos livros que tenham se debruçado para escrever sobre a vida de Francisco Juliāo ou uma parte dela. Pode-se citar uma dissertação defendida no Programa de Pós-graduação em História da Universidade de São Paulo que trata especificamente do período do exílio: CASTELLANOS, Diana G. Hidalgo. Um olhar na vida de exílio de Francisco Julião. Dissertação (Mestrado em História) - Faculdade de Filosofia Letras e Ciências Humanas, Universidade de São Paulo, São Paulo, 2002, e dois livros escritos pelo jornalista Vandeck Santiago: SANTIAGO, Vandeck. Francisco Julião: luta, paixão e morte de um agitador - Coleção Perfil Parlamentar Século XX. Assembleia Legislativa do Estado de Pernambuco. Recife, 2001; Francisco Julião, as Ligas e o golpe militar de 64. Recife: Comunigraf, 2004. Em 2014 foi lançada uma biografia de mais de 800 páginas de autoria do escritor Cláudio Aguiar: Francisco Julião, uma biografia: o homem e a política, as ligas camponesas e a reforma agrária, exílio e ocaso. 1. ed. Rio de Janeiro: Civilização Brasileira, 2014. ${ }^{8}$ FERREIRA, Jorge. João Goulart: uma biografia. Rio de Janeiro: Civilização Brasileira, 2011, p. 500.

9 SKIDMORE, Thomas. Brasil: de Getúlio a Castelo. 1930-1940. 7. ed. Rio de Janeiro: Paz e Terra, 1982, p. $273-274$.
} 
ponesas, que em princípios de 1961 esteve em Cuba e em novembro desse mesmo ano atuou com destaque no Congresso Nacional de Camponeses em Belo Horizonte, onde foi aprovada a proposta de reforma agrária radical. Essas atuações são apropriadas pelas análises de Skidmore ao considerar que, após o congresso, a violência na zona rural tornou-se mais frequente e a radicalização política nesse setor aumentou, causando problemas para o governo de João Goulart. ${ }^{10}$

Destaco ainda dois outros livros publicados em espanhol, um sobre a história do Brasil e outro acerca da América Latina, que estabelecem uma relação entre o dirigente das Ligas e o golpe civil-militar de 1964. No primeiro caso, Carlos Guilherme Mota e Adriana Lopez escreveram História de Brasil: una interpretación, lançado pela Universidade de Salamanca, em 2009, no qual afirmam que "as Ligas Camponesas, lideradas pelo advogado Francisco Julião, provocaram a direita com a ameaça de uma revolução camponesa socialista, seguindo o exemplo da Revolução Cubana”."11

Nessa linha de análise, o cientista político Alain Rouquié, ${ }^{12}$ ao tratar sobre a América Latina no seu livro Introdución al extremo Occidente, publicado pela editora Siglo XXI, em 1989, afirmou: “Assim, sabemos que as Ligas Camponesas organizadas por Francisco Juliáo no Nordeste brasileiro foram um dos detonadores da mobilização que conduziu ao golpe de Estado de 1964". 13

Esse tipo de abordagem insere-se em uma construção social que aponta as açóes das Ligas Camponesas e de seu líder, com seus discursos classificados de radicais e revolucionários, como contribuintes para o golpe. Neste artigo, saber se Francisco Julião era radical ou se o movimento que liderou funcionou como estopim para o golpe não é uma questão. O interesse é investigar como ele operou com o seu passado de líder das Ligas Camponesas e as alegaçóes de culpado, radical, incendiário, colocando sua memória individual e uma memória coletiva em diálogo ${ }^{14}$ com a escrita sobre o tempo presente, nesse caso, o processo de redemocratização Brasil. Nessa perspectiva, como contraponto às abordagens que o apresentam exclusivamente pelas suas açóes anteriores de 1964, este estudo privilegia alguns dos seus escritos durante o processo de abertura política do país.

Em um primeiro momento, investiguei como esse passado de Francisco Juliáo, líder das Ligas Camponesas, é atualizado na década de 1980. Para isso, analisei o lançamento da Cartilha do trabalhador do campo, em 1981, escrita por Francisco Julião, e sua repercussão na imprensa de Pernambuco. Estudei como a divulgação desse documento rememorou outro

${ }^{10}$ SKIDMORE, Thomas. Brasil: de Getúlio a Castelo. 1930-1940, op. cit., p. 273-279.

${ }^{11}$ MOTA, Carlos Guilherme; LOPEZ, Adriana. História de Brasil: una interpretación. 1. ed. Salamanca Ediciones, 2009, p. 557.

${ }^{12}$ Foi embaixador da França no Brasil entre 2000 e 2003.

${ }^{13}$ ROUQUIÉ, Alain. América Latina. Introducción al extremo occidente. México: Siglo Veintiuno editores, 1989, p. 114.

${ }^{14} \mathrm{~A}$ evocação dos fatos políticos, matéria da memória coletiva, aparece misturada às impressões da memória individual. HALLBWACHS, Maurice. A memória coletiva. São Paulo: Vértice, 1990. 
texto produzido pelo político de esquerda, a Cartilha do camponês, utilizada para a mobilização de milhares de trabalhadores rurais antes do golpe de 1964.

Essa rememoração é a produção de uma memória voluntária, no sentido oferecido por Gilles Deleuze ao estudar a obra de Marcel Proust, e isso significa que "ela não se apodera diretamente do passado, mas o recompóe com os presentes", ${ }^{15}$ neste caso o da redemocratização do Brasil. A historiadora Regina Guimarães alerta que se deve ainda identificar os "jogos de linguagem, produtores de efeitos encenativos [...] por mais rico que seja qualquer relato acerca de trajetórias individuais, o que mais importa é a sua especificidade nas articulaçôes com a memória coletiva". ${ }^{16}$

Nesse sentido, analisei os relatos agenciadores do passado pré-1964 elaborados por Francisco Julião ou sobre ele enquanto produtores de efeitos e como um texto onde "se inscrevem desejos e reproduzem-se modelos". ${ }^{17}$ Com efeito, procurei articulá-los com o presente da redemocratização e seus múltiplos contextos, onde as práticas e discursos de radicalização política não eram aceitos.

Em um segundo momento, estudei os escritos políticos de Francisco Juliáo, especificamente os textos intitulados Cartas do Nordeste, produzidos por ele entre 1984 e 1985, no contexto do movimento de Diretas Já. Esses escritos políticos são pouco conhecidos pela historiografia, como grande parte da sua produção após o regresso ao Brasil em 1979. São textos datilografados e manuscritos, nos quais Julião registrava sua leitura sobre o processo de redemocratização do Brasil, o movimento de Diretas Já e sua forma de atuação nesse período. Não consegui encontrá-los publicados. Julião dizia que as Cartas foram solicitadas pelo Espaço Democrático. Em uma conversa com seu filho, Anacleto Julião, soube que esse seria uma publicação do PDT. Nunca encontrei seus exemplares. Esses escritos são tomados não para saber o que houve nesses processos do início dos anos 1980 no Brasil, mas sim o que o autor "diz que viu, sentiu e experimentou" em relação a eles, produzindo-se. ${ }^{18}$ Assim, esses escritos registram como Francisco Julião procurou construir uma identidade política, que se produz em referência aos outros, em referência aos critérios de aceitabilidade, de admissibilidade, de credibilidade, ${ }^{19}$ em parte definidos, em meados dos anos 1980, pelo movimento das Diretas Já. Por fim, as Cartas do Nordeste resultam de um esforço de Julião documentar sua atuação no processo de redemocratização do Brasil. Dialoga com o passado, mas pensa no futuro, atuando como um arquiteto da memória,

\footnotetext{
${ }^{15}$ DELEUZE, Gilles. Proust e os signos. Rio de Janeiro: Forense Universitária, 2006, p. 54.

${ }^{16}$ GUIMARÁES NETO, Regina Beatriz. Cidades da mineração - memórias e práticas culturais. Mato Grosso na primeira metade do século XX. Cuiabá: Carlini \& Caniato: EdUFMT, 2006, p. 46.

${ }^{17}$ GUIMARÁES NETO, Regina Beatriz. Cidades da mineração - memórias e práticas culturais. Mato Grosso na primeira metade do século XX, op. cit., p. 47.

${ }^{18}$ GOMES, Angela de Castro. Escrita de si, escrita da História: a título de prólogo. In: (Org.). Escrita de si, escrita da História. Rio de Janeiro: Editora FGV, 2004.

${ }^{19}$ POLLAK, Michael. Memória e identidade social. Estudos Históricos, Rio de Janeiro, v. 5, n. 10, 1992, p. 200-212. p. 5.
} 
aquele que está preocupado em passar as geraçōes futuras ensinamentos, razôes e estratégias na escolha de determinadas decisöes. ${ }^{20}$

\section{Cartilha(s)}

Em 1981, Francisco Julião escreveu a Cartilha do trabalhador do campo. Lançava mão de uma estratégia já empregada entre os anos 1950 e 1960 na mobilização de camponeses no Nordeste do Brasil, quando lançou a Cartilha do camponês e outros textos que se dirigiam diretamente ao trabalhador rural.

Está na hora de conversar contigo, trabalhador do campo, diarista, tarefeiro, limpador de mato, cortador de cana, cuidador de gado, rendeiro, vaqueiro e dono de meio palmo de terra. Há muitos anos a minha conversa foi com o foreiro, o oiteiro, o meeiro, que lidavam de sol a sol, sujeitos a tudo e sem direito a nada. Aquela conversa começou em 40, mas só em 45 pude dar o primeiro grito contra o CAMBÃO. Dez anos depois, em 55, nasce a primeira Liga, ali na Galileia, com o velho Zezé à frente. O camponês pobre, sem terra, foi tomando chegada. No começo, desconfiado, e até com medo. Perguntando: "É de lei?". E a gente respondendo: "É de lei". Foi assim que a Liga cresceu e se multiplicou. Espalhou-se pela Zona da Mata e pelo Agreste. Depois pela Paraíba, o Rio Grande do Norte e as Alagoas. Finalmente, pelo Brasil. É das entranhas da Liga que nasce o Sindicato. Ali pelo ano de 61. Depois do grande Congresso Nacional Camponês, em Belo Horizonte. A Liga cumpriu o seu papel. Deu heróis e deu mártires. Passou para a História. Mas aí está o Sindicato. ${ }^{21}$

De início, o leitor pode atentar para uma questão: a palavra camponês não aparece no título, como na Cartilha do camponês, do ano de 1960. Em 1981, era "trabalhador do campo". O primeiro era um termo que atualizaria um passado de intensa mobilização de um segmento social, que marchou para as cidades e ocupou terras, carregando grandes cartazes com a imagem de revolucionários, como Ernesto Che Guevara e Fidel Castro, e entoando gritos de "reforma agrária na lei ou na marra". Não era isso que Francisco Julião desejava lembrar do passado. ${ }^{22}$

\footnotetext{
${ }^{20}$ Definição utilizada por Antonio Montenegro para analisar os escritos de Dom Fragoso, Arcebispo de Crateús entre 1964 e 1998; MONTENEGRO, Antonio Torres. Arquiteto da memória: nas trilhas dos sertôes de Crateús. In: . História, metodologia, memória. São Paulo: Contexto, 2010, p. 116.

${ }^{21}$ Cartilha do trabalhador do campo. Datilografada e com acréscimos manuscritos. 15 de agosto de 1981 . FJ PIp 5 doc 41,4. CEHIBRA, Fundaçâo Joaquim Nabuco.

${ }^{22}$ Quando, na década de 1950, Francisco Julião utilizou o termo camponês em um discurso na Assembleia Legislativa de Pernambuco, foi aparteado por uma deputada que lhe dizia ter o termo uma carga política e ideológica muito grande. Julião não recuou de sua posição. $\mathrm{O}$ uso da expressão instituía uma nova prática, que provocava receios na sua colega e em diversos setores sociais. O que se seguiu foram congressos de cam-
} 
Ao usar "trabalhador do campo", ele passava a operar com a denominaçáo que foi oficialmente adotada pelos sindicatos rurais. Direcionava seu texto para os representantes de novas formas de trabalho no meio rural e que não participaram do movimento das Ligas Camponesas. Eram ainda pessoas que estavam ou deveriam estar nos sindicatos de trabalhadores rurais espalhados pelo interior de Pernambuco nos anos 1980.

Mas o sindicato, segundo Julião, nasceu do trabalho realizado pelas Ligas Camponesas. Esse argumento já tinha aparecido também em seu próprio livro, Cambâo, escrito no México no final dos anos 1960, e foi a temática principal do documento Bença, mãe! lido para cerca de 10 mil pessoas em uma praça no centro do Recife, em 2 de janeiro de 1964. Nesta ocasiáo se dizia: "A liga é a mãe do sindicato." ${ }^{23}$ Nesses dois últimos escritos, enfatizava-se a dimensão de que enquanto as Ligas lutavam por terra e salário, o sindicato direcionava suas açôes apenas para o salário. No seu livro, a reflexão construída era a seguinte: "a Liga tinha razão para temer que a luta pura e simples pelo salário amortecesse ou anulasse o impulso do camponês no sentido de conquistar a terra, que é o objetivo fundamental". ${ }^{24}$

$\mathrm{Na}$ Cartilha do trabalhador do campo de 1981, Juliáo voltava a afirmar que o sindicato surgiu das "entranhas da Liga". Construía um lugar de autoridade para o seu discurso ao afirmar que a mobilização sindical daquele momento resultava das lutas e conquistas realizadas pelo movimento do qual ele foi um dos principais articulador e líder. Ao estabelecer uma linha de continuidade das Ligas aos sindicatos rurais, projeta-se como responsável também pela criaçáo dos sindicatos.

Na referida Cartilha há uma convocação para que os trabalhadores participem dos sindicatos. Convocar parentes, vizinhos e amigos a se organizar e dessa forma melhor lutar pela garantia do salário mínimo, do repouso semanal remunerado, do décimo terceiro, das férias, da assistência médica e dentária, da escola para os filhos, da aposentadoria, do direito à greve e da terra para trabalhar.

A pauta de reivindicação contemplava não apenas as questôes relacionadas com as condiçôes de trabalho, mas as próprias condiçôes de vida. Foi atualizada para os debates dos anos 1980. A questão do direito à terra não tinha mais a centralidade existente na cartilha de 1960. Não se falava da conquista da terra por meio de uma reforma agrária, nem na lei, nem na marra.

A Cartilha do trabalhador do campo foi impressa e distribuída. ${ }^{25} \mathrm{O}$ Jornal do Commercio de 13 de janeiro de $1982^{26}$ traz uma reportagem sobre essa publicação e, ao mesmo tempo,

ponês, expansão das Ligas e passeatas pelas ruas centrais do Recife. A discussão está em MONTENEGRO, Antonio Torres. Ligas Camponesas e sindicatos rurais em tempo de revolução. In: História, metodologia, memória, op. cit., p. 84.

${ }^{23}$ Bença, mãe! O texto desse documento foi transcrito na íntegra no livro Cambão: a face oculta do Brasil, p. 215-224. JULIÃO, Francisco. Cambão: a face oculta do Brasil. Recife: Bagaço, 2009

${ }^{24}$ JULIÁO, Francisco. Cambão: a face oculta do Brasil, op. cit., p. 214.

${ }^{25}$ Não consegui ter acesso ao texto impresso. Usei uma versão datilografada, com acréscimos manuscritos, arquivada na Fundaj, e que foi a base da publicação.

${ }^{26}$ Jornal do Commercio, 13 de janeiro de 1982. p. 5. APEJE. 
comenta a não participação de Julião nas eleiçóes que se aproximavam: "Julião desiste de ser deputado e faz cartilha de camponês". ${ }^{27}$ Teófilo Silva, jornalista que escreveu a matéria, afirmava que o ex-líder das Ligas Camponesas estava voltando às suas atividades do pré-1964. Assim, o título da reportagem já anunciava que a decisão de não concorrer a uma vaga no Congresso Nacional era unicamente de Francisco Julião. Dessa maneira, a desistência da candidatura náo teria relaçáo com a reforma eleitoral de 1981 e o estabelecimento do voto vinculado, aparecendo associada à opção pela retomada do trabalho com o camponês. A reportagem decretava que a "Cartilha do trabalhador do campo marcava uma nova etapa de Julião junto ao trabalhador do campo". ${ }^{28}$

Após transcrever algumas passagens do texto da cartilha, Teófilo Silva comentava o que considerava ser o seu maior significado: "Nas entrelinhas das suas liçôes sobre o sindicalismo Julião deixa claro que voltará aos campos, revivendo os dias em que camponeses queriam, partindo da Galileia, marchar contra o Recife” ${ }^{29}$ O passado de mobilização das Ligas Camponesas era atualizado na leitura da Cartilha de 1981.

O jornalista havia entrevistado o ex-líder camponês, o qual teria lamentado "que forças estranhas tenham se infiltrado nas Ligas Camponesas e as conduzido ao terror" ${ }^{30}$ Em seguida, o leitor encontrava aquilo que seria a transcrição de uma declaração de Francisco Julião: "Nunca pretendi derramamento de sangue, tomada de terra na marra, nem anarquia. Fontes estranhas é que pretenderam a conturbação entre os camponeses para atingirem objetivos que eu condenava”. ${ }^{31} \mathrm{O}$ autor da cartilha retomava acusaçóes realizadas por seus adversários, que o indicavam como responsável de promover açóes radicais, para mais uma vez tentar refazer, ressignificar, desconstruir a memória das Ligas associada à desordem e à violência.

A apresentação na imprensa da nova publicação de Francisco Julião para o trabalhador rural tornou-se um tipo de inquérito sobre as suas ações anteriores ao golpe civil-militar de 1964, relembrando ao leitor que elas promoveram um sentimento de "terror". E ao estabelecer uma ponte entre esse passado e o presente da redemocratização do país, Teófilo Silva lançava uma série de incertezas sobre essa nova atuação de Francisco Julião junto aos trabalhadores rurais:

O fato é que Francisco Julião viverá em Pernambuco uma nova história do campo. Conseguirá repelir as "forças estranhas"? Evitará que os camponeses empunhem foices e facas e voltem a conturbar a vida nos campos? Evitará as greves, os assassinatos, as depredaçóes de usinas, as queimas de canaviais? Talvez Julião diga que somente o futuro dirá. Futuro, queira Deus, não seja tâo negro quanto os últimos dias que antecederam $64 .{ }^{32}$

\footnotetext{
${ }^{27}$ Jornal do Commercio, op. cit.

${ }^{28}$ Jornal do Commercio, op. cit.

${ }^{29}$ Jornal do Commercio, op. cit.

${ }^{30}$ Jornal do Commercio, op. cit.

${ }^{31}$ Jornal do Commercio, op. cit.

${ }^{32}$ Jornal do Commercio, op. cit.
} 
As perguntas do texto lembravam fatos antes que eles acontecessem. Operava-se com uma memória sobre Julião que fazia sentir o perigo do futuro, materializado em foices, facas, greves e queimas de canaviais. Antecipava-se um possível cenário ameaçador antes de Julião voltar a atuar no campo. Seria um déjà vu. Tentando se contrapor a esse movimento, ele já vinha respondendo a esses questionamentos desde os últimos anos do seu exílio. Em entrevistas concedidas no final da década de 1970, ele falava que não reativaria as Ligas Camponesas, negava ter comandado invasóes de terras e ordenado incêndios de canaviais. Tentava desfazer qualquer caracterização de suas açóes como sendo algo violento e ilegal. Mas, todo esse seu esforço parecia limitado. A Cartilha, que nada falava sobre reforma agrária, invasão de terras ou marcha dos camponeses, foi apresentada, pelo Jornal do Commercio, como a prova de que Francisco Juliáo voltaria a atuar no campo e poderia haver violências e desordens. Afinal, é possível que os leitores mais idosos que vivenciaram o pré-64 tenham pensado: era o Julião escrevendo outra vez cartilhas e isso se relacionaria a camponeses marchando pelas cidades e ocupando terras.

A Cartilha do trabalhador do campo não sofreu uma censura oficial da Divisão de Censura do Estado, mas o jornal utilizou de uma argumentação próxima à usada por representantes do governo naquele período de transição: a de que Julião poderia "reavivar" situaçóes que não deveriam regressar. Esse foi o argumento utilizado pelo governo militar para censurar a exibição pública do disco Julião, verso e viola, lançado em 1981. A produção foi realizada pelo Selo Libertas/Disco Independente e assinada por Herbert de Souza, o Betinho. O LP era composto por três faixas, nas quais Francisco Julião recitava três longos textos, a saber: Os direitos da mulher, apresentado no lado A, tinha 11 minutos de duração; Porque sou nacionalista e $O$ sindicato é a estrela estavam no lado B do disco e juntos totalizavam pouco mais de 23 minutos de gravação.

Ao final do ano de 1982, duas de suas produçóes pós-exílio, o disco e a cartilha, enfrentavam dificuldades para circular. Não há indícios de que esta última, a qual continha oito páginas e algumas ilustraçôes, tenha alcançado ampla repercussão. No período anterior ao golpe de 1964, contudo, praças eram tomadas por pessoas desejosas de escutar a leitura dos textos de Francisco Julião. ${ }^{33}$

\section{As cartas}

Entre o final de 1983 e o início de 1984, o Brasil viveu uma mobilização social nova, se tomado como referência o período da ditadura. Milhares de pessoas se reuniram nas ruas e

\footnotetext{
${ }^{33}$ Francisco Julião afirma que 10 mil pessoas estiveram na Praça Dantas Barreto, em Recife, no dia 2 de janeiro de 1964, quando ele realizou a leitura do texto Bença, máe!! Na ocasião comemorava-se o quinto aniversário da vitória da Revolução Cubana. JULIÃO, Francisco. Cambão: a face oculta do Brasil, op. cit., p. 215.
} 
praças públicas de várias cidades em diferentes estados do país para exigir mudanças. Confluíam trabalhadores, artistas, cantores e políticos. Muitos discursos proferidos e músicas cantadas. Em alguns locais, papéis picados atirados do alto dos prédios alegravam esses momentos e promoviam a ideia de comemoração. Era a mobilização pela volta das eleições diretas para Presidente da República, o que não ocorria no Brasil desde 1960, quando Jânio Quadros foi eleito. Reivindicava-se o fim do Colégio Eleitoral, um dos principais instrumentos de controle político dos governos militares e peça-chave na estratégia de liberalização adotada pelo regime militar. ${ }^{34}$ Assistia-se ao movimento das Diretas Já!

As manifestações das ruas foram acompanhadas de uma intensa participação dos partidos; PMDB, PDT, PT formaram o Comitê Nacional Partidário Pró-Diretas. Integravam também o movimento das Diretas Já o PCB e o PC do B, ainda ilegais, e instituições da sociedade civil, como a Ordem dos Advogados do Brasil (OAB) e a Associaçáo Brasileira de Imprensa (ABI)..$^{35}$ Essa foi "talvez a única campanha popular nascida do Parlamento", afirmou em 2004 Domingos Leonelli, um dos autores do livro Diretas Já: 15 meses que abalaram a ditadura. Dante de Oliveira, também autor do livro, em 1983 era um jovem deputado federal, recém-eleito pelo PMDB. Naquela ocasiâo o parlamentar propôs uma emenda constitucional com 15 linhas que versava sobre o restabelecimento da eleição direta para presidente da república. ${ }^{36} \mathrm{~A}$ proposta passou a tramitar no Congresso Nacional após receber a assinatura de 23 senadores e 177 deputados e foi votada em plenário mais de um ano depois, em abril de 1984.

Os comícios pelas Diretas Já ocorriam entre as crises e as negociaçóes políticas. Em janeiro de 1984, no Largo do Amparo, em Olinda, concentraram-se cerca de 30 mil pessoas. Dias antes, na Praça de Sé, em São Paulo, estiveram presentes aproximadamente 200 mil pessoas. Viajaram para o evento em Olinda os governadores de Minas Gerais, Tancredo Neves, e de São Paulo, Franco Montoro. Leonel Brizola, do Rio de Janeiro, que havia confirmado a presença, desistiu de vir na última hora. O PDT foi representado no palanque pelo seu presidente nacional, Doutel de Andrade, e por Francisco Julião. Juntaram-se a eles Ulysses Guimarães, Miguel Arraes, Jarbas Vasconcelos e o presidente do Partido dos Trabalhadores, Luiz Inácio da Silva. Roberto Magalhães, governador de Pernambuco, anunciou apoio à mobilização. Ofereceu a logística necessária para a realização do comício, mas não se fez presente. ${ }^{37}$

\footnotetext{
${ }^{34}$ RODRIGUES, Alberto Tosi. Diretas Já: o grito preso na garganta. São Paulo: Editora Fundação Perseu Abramo, 2003, p. 11-12. O caráter festivo da população ocupando as ruas também é destacado em DELGADO, Lucilia de Almeida Neves. Diretas Já: vozes das cidades. In: FERREIRA, Jorge; REIS FILHO, Daniel Aarão. Revolução e democracia (1964...). Rio de Janeiro: Civilização Brasileira, 2007, p. 413 e LEONELLI, Domingos; OLIVEIRA, Dante. Diretas Já: 15 meses que abalaram a ditadura. Rio de Janeiro: Record, 2004. ${ }^{35}$ DELGADO, Lucilia de Almeida Neves. Diretas Já: vozes das cidades. In: FERREIRA, Jorge; REIS FILHO, Daniel Aarão. Revolução e democracia (1964...), op. cit., p. 414.

${ }^{36}$ Apresentação escrita por Ronaldo Costa Couto para o livro Diretas Já: 15 meses que abalaram a ditadura, op. cit., p. 25.

${ }^{37}$ Essas informaçóes ocuparam as páginas dos principais jornais do estado, Diario de Pernambuco e Jornal do Commercio, entre os dias 27 e 28 de janeiro de 1984.
} 
A participação de Francisco Juliáo não teve destaque na imprensa. Não encontrei matéria ou nota publicada nos dias que se seguiram ao comício. Integrar-se ao movimento das Diretas Já era atuar junto à rede política engajada na redemocratização do Brasil. Era também uma maneira de ter mais visibilidade, retomar os discursos em praça pública. Deve-se lembrar que entre 1981 e 1982 Julião havia sido censurado pelo governo militar, que vetou a exibição pública do seu disco, além de ter sido alvo de críticas do Jornal do Commercio pelo lançamento da Cartilha do trabalhador do campo.

Durante os meses de mobilizaçáo por eleiçôes diretas para presidente, poucas referências a Francisco Julião foram publicadas na imprensa. No entanto, este mantinha a prática da escrita política que tão intensamente desenvolvera nos anos de exílio no México. ${ }^{38}$ Redigiu uma série de textos sob o título de Carta do Nordeste. ${ }^{39}$ Desenvolveu análises acerca dos políticos envolvidos na campanha das Diretas Já e na luta de redemocratização do país. Esses escritos possibilitam cartografar os próprios deslocamentos do autor em face também das leituras que operava da conjuntura brasileira. São escritas de $\mathrm{si}^{4}{ }^{40}$ sobre seus posicionamentos políticos e sobre seu passado.

Em janeiro de 1984, antes do comício do Largo do Amparo, em Olinda, a primeira Carta do Nordeste foi lançada. A região era representada como um lugar de pobreza, de resistência e de lutas. Dizia-se de um território esquecido e injustiçado, inclusive pelos que nele nasceram, mas se deixaram encantar pelo centro-sul. $\mathrm{O}$ autor, ao contrário, se apresentava como alguém que vivia pelo e para o Nordeste. ${ }^{41}$ Assim concluiu sua primeira carta, prometendo voltar ao tema no escrito seguinte. Usa de um discurso regionalista para criar uma identidade para si, que nesse momento se aproximava do Francisco Juliáo das Ligas Camponesas do Nordeste do Brasil da década de 1960.

No início do mês seguinte, as análises sobre a regiáo passaram a ser relacionadas a uma questâo mais específica: a campanha das Diretas Já. Julião se mostrava animado com as possibilidades de mudanças que a mobilização popular e as eleiçôes diretas para presidente poderiam promover. Falava das ameaças que considerava existir caso continuasse as eleiçôes indiretas. "Indiretas a esta altura? É uma bofetada, um insulto, uma coronhada, um convite ao caos, à anarquia". E continua: "O Nordeste está de pé, com a sua fome, a sua pobreza, o seu abandono, sustentando que só as DIRETAS (sic) apagarão o fogo que o Colégio Eleitoral ateia pelo Brasil". ${ }^{2}$

\footnotetext{
${ }^{38}$ Durante o exílio, Francisco Juliāo escreveu cerca de 300 artigos sobre questôes políticas da América Latina na revista Siempre!. Com publicação semanal, nas décadas de 1960 e 1970, esse era um dos principais periódicos lidos por intelectuais de esquerda, estudantes e uma elite política ligada ao Partido Revolucionário Institucional (PRI).

${ }^{39}$ Algumas das Cartas estão apenas manuscritas e outras datilografadas.

${ }^{40}$ GOMES, Angela de Castro. Escrita de si, escrita da História: a título de prólogo, op. cit., p.15.

${ }^{41}$ Carta do Nordeste. 19 de janeiro de 1984. FJ PIp 4 doc 28,1. CEHIBRA, Fundação Joaquim Nabuco.

${ }^{42}$ Carta do Nordeste. 2 de fevereiro de 1984. FJ PIp 5 doc 32,3. CEHIBRA, Fundação Joaquim Nabuco.
} 
O discurso era ameaçador: ou eleiçóes diretas ou o caos, porque a pobreza do Nordeste não aceitaria "indiretas" outra vez. Julião operava com uma lógica próxima àquela, do início dos 1960, que anunciava "reforma agrária na lei ou na marra", porque para isso disporia de milhares de pobres camponeses organizados para lutar. ${ }^{43}$ Atualizando para os anos 1980, seriam eleiçôes diretas ou o convite ao caos de um pobre Nordeste que já estava de pé.

Ao mesmo tempo, se por um lado indicava um possível levante contra as Indiretas e assim contra o governo que a sustentava, por outro assinalava que: "O Nordeste náo quer a guerra. Quer a paz. Paz com dignidade, com eleiçôes diretas, para um novo pacto social, uma nova Carta Magna". ${ }^{44}$ Esse posicionamento se aproximava de outro apresentado no final de 1978, quando Juliáo, ainda no exílio, respondendo ao entâo futuro presidente Joâo Figueiredo, que ameaçava não anistiá-lo, afirmava por meio da revista mexicana Siempre!: Não levantaria barricadas nas ruas no dia em que se incorporasse à luta do povo brasileiro. ${ }^{45}$ Ou seja, não desejaria a guerra, o confronto. Tanto o exilado de 1978 quanto o anistiado de 1984 demonstravam uma preocupação em desfazer qualquer posição de enfrentamento com o governo militar, apesar de operacionalizarem ao mesmo tempo um discurso com tons ameaçadores.

Uma característica, entretanto, atravessava todo o texto da carta e dizia respeito ao seu entusiasmo com a possibilidade de mudanças vislumbrada no movimento das Diretas Já. Mudanças que promoveriam um novo pacto social e uma Constituinte.

Os meses de março e abril foram de novos comícios. Nas suas maiores manifestaçôes, cerca de 1 milhão de pessoas estiveram na Candelária, Rio de Janeiro, em 10 de abril, e aproximadamente 1 milhão e meio no Vale do Anhangabaú, São Paulo, no dia $16 .{ }^{46} \mathrm{~A}$ mobilização de milhares de pessoas em quase todo o país, envolvendo artistas, cantores e mesmo atletas, que chegavam a comandar alguns comícios, pressionou políticos da situação e da oposição a reavaliarem algumas posturas. No final de 1983, 12 governadores situacionistas haviam aderido à ideia de uma eleição direta para presidente em 1985. No PMDB, Ulysses Guimarães e Tancredo Neves decidiram adiar o debate sobre a posiçáo do partido no processo de redemocratizaçáo. Ou seja, se o PMDB adotaria a estratégia de negociar um acordo com o Regime ou efetivamente se tornaria a expressão da vontade manifestada na campanha das Diretas Já.

\footnotetext{
${ }^{43}$ Francisco Julião, em seu último discurso no Congresso Nacional, em 31 de março de 1964, afirmou: "podemos dispor de 500 mil camponeses para responder aos gorilas como os gorilas quiserem. Na lei, como desejamos; na marra, se eles quiserem. Estamos com nossa casa arrumada”. SANTIAGO, Vandeck. Francisco Julião: luta, paixão e morte de um agitador. Coleção Perfil Parlamentar Século XX. Recife: Assembleia Legislativa do Estado de Pernambuco, 2001, p. 155.

${ }^{44}$ Carta do Nordeste. 2 de fevereiro de 1984. FJ PIp 5 doc 32,3, op. cit.

${ }^{45}$ Revista Siempre!, 25 de outubro de 1978. n. 1322, p. 42-43. Instituto de Investigaciones Bibliográficas Hemeroteca Nacional — UNAM, México.

${ }^{46}$ Esses números são estimados por Alberto Tose Rodrigues a partir da pesquisa em quatro periódicos do período: Folha de S. Paulo, O Estado de S. Paulo, Veja e Isto é.
} 
A mobilização social produziu novos cenários. Alguns anteviam um enfrentamento com o governo. Outros desejavam o caminho da negociação, como Tancredo Neves. Para ele o cenário político era paradoxal, pois ao mesmo tempo em participava da campanha por eleiçóes diretas, organizando inclusive o comício de Belo Horizonte, procurava garantir e ampliar sua credibilidade junto a alguns setores do governo militar. ${ }^{47}$

Em março de 1984, enquanto milhares de pessoas seguiam mobilizadas, o Palácio do Planalto se preocupava com os altos índices de reprovação ao Presidente João Figueiredo e o racha dentro do PDS, que resultou na formação de um grupo pró-diretas. Francisco Juliáo escrevia mais uma carta intitulada: Política, Democracia e Povo. O Nordeste não era mais a temática dos seus escritos. Agora, ele estava voltado para o debate sobre eleiçôes, redemocratização e participação popular. E dizia:

Por que então se questiona tanto a Política? A resposta é fácil. Porque a Política, que é Ciência e é Arte, tem como projeção e finalidade, o Povo. É a própria essência da Democracia. Assim, Política, Democracia e Povo formam um todo indivisível. É uma totalidade. Um universo. Sempre que essa trilogia é questionada em uma de suas partes, o todo é afetado. ${ }^{48}$

Esse discurso de Julião não o aproximava dos setores políticos, como os moderados do PMDB, que receavam os resultados do movimento das Diretas. Para esses, o "povo" era importante, mas enquanto oferecesse ganhos no momento de negociação com o Regime. A mobilizaçáo popular deveria representar a ruptura com qualquer intenção de continuísmo do governo militar. Esse era o seu limite. Não poderia destruir os caminhos institucionais das eleiçóes indiretas que seriam utilizados por essa parte da oposição e da situação, que se distanciava dos militares, para alcançar a Presidência no processo sucessório. ${ }^{49}$

Na carta, Política, Democracia e Povo eram elementos inseparáveis, sendo esse último apresentado como o limite da democracia. ${ }^{50}$ Francisco Julião não demonstrava receio de um retrocesso da abertura, como consequência de uma possível radicalizaçáo das Diretas. Para o autor, o processo político de democratização do país exigiria a presença e a participaçáo do "povo". ${ }^{51} \mathrm{O}$ presidente nacional do PDT, Doutel de Andrade, apresentou posicionamento

\footnotetext{
${ }^{47}$ RODRIGUES, Alberto Tosi. Diretas Já: o grito preso na garganta, op. cit., p. 44-48.

${ }^{48}$ Carta do Nordeste. Política, Democracia, Povo. 22 de março de 1984. FJ PIp 5 doc 35,1. CEHIBRA, Fundação Joaquim Nabuco.

${ }^{49}$ RODRIGUES, Alberto Tosi. Diretas Já: o grito preso na garganta, op. cit., p. 49-53.

50 "Quem politiza, educa, prepara, orienta, abre espaço para o funcionamento da Democracia plena, cujo limite é o povo". Trecho da Carta do Nordeste. Política, democracia, povo, op. cit.

${ }^{51}$ Um mês antes dessa Carta de março de 1984, ocorreu uma reunião em Brasília, da qual participaram o presidente João Figueiredo, o vice-presidente Aureliano Chaves, alguns ministros e lideranças do PDS — José Sarney, Marco Maciel e Paulo Maluf. Foi apresentado um relatório do SNI, que classificava o movimento das Diretas Já como sendo uma escalada esquerdista e uma ameaça à segurança nacional. Os ministros militares ressaltaram que a continuidade do processo de abertura dependia das eleiçóes indiretas e mediante um agravamento da crise, um retrocesso político poderia ocorrer. Tancredo Neves, o líder dos moderados do PMDB,
} 
semelhante no comício em Belém, no dia 17 de fevereiro: "contra o desejo de 120 milhóes de brasileiros o governo pretende impor a vontade de quatro cidadáos. [...] O regime autoritário morreu. Quem o matou foi o povo na praça pública".52

Julião apostava na possibilidade de mudança. As manifestaçóes nas ruas poderiam criar uma nova força social com poder de interferir no jogo partidário-político, abrindo espaço para a ação de novos atores sociais ou mesmo de antigos que, como ele, estavam fora da elite política da transição. Neste caso, setores situacionistas e da oposição considerada moderada, que tendiam para a negociação, passariam a ter ameaçada sua hegemonia sobre o processo de redemocratização em curso.

Em outra carta datada de março de 1984, Juliáo classificava a elite política como sendo "os incendiários, os pirômanos, os que querem tocar fogo no Brasil". ${ }^{53}$ Deve-se ver que aqui há uma tentativa de inversão de uma dinâmica acusatória. O ex-dirigente camponês, acusado de ordenar os incêndios de canaviais no início da década de 1960, atribuía a seus adversários a imagem de incendiário. Nomeia aqueles que assumiram o governo com o golpe de 1964 de subversivos. "Foi a elite, que tomou conta do poder pela violência. Que iludiu toda a Nação. Que estatizou nossas riquezas para mais facilmente entregá-las as transnacionais. [...] E não contente, a casta que nos domina, oprime e chantageia, fala em prorrogar o poder em mais seis anos". ${ }^{4}$

A referência era aos militares e setores civis que defendiam as eleiçóes indiretas. Eles seriam os subversores da ordem democrática em 1964 e que desejavam incendiar a nação ao se contraporem às Diretas Já:

Querem tocar fogo no circo. E são eles os incendiários! Nós, todos nós, que queremos restaurar a democracia plena, reconquistar a dignidade, que o País perdeu, nós, os que pugnamos, abertamente, na praça pública, pelo direito de eleger, em 85, o Presidente da República, nós somos, hoje, os bombeiros do Brasil.

Sim, os bombeiros..$^{5}$

reverberava essa posição ao afirmar sua análise sobre aquela reunião na imprensa: "O que nos salta aos olhos é que estamos no inicio de um pequeno retrocesso na abertura democrática”. Revista Veja, 22 de fevereiro de 1984. p. 21. O jornalista Carlos Castello Branco também avaliou a situação como sintoma de um retrocesso. ${ }^{52}$ Os oradores do comício de Belém tentaram responder à reunião ocorrida dois dias antes em Brasília (citada na nota anterior), entre governo e lideranças do PDS, que lançou nota reafirmando a eleição indireta. Ulysses Guimarães e Luiz Inácio da Silva apresentaram posicionamentos próximos ao de Doutel de Andrade. Para alguns trechos dos discursos no comício ver, KOTSCHO, Ricardo. Explode um novo Brasil. Diário da Campanha das Diretas. Ed. Brasiliense: São Paulo, 1984. p. 43.

${ }_{53}$ Carta do Nordeste. Incendiários e bombeiros. Março de 1984. FJ PIp 4 doc 31,3. CEHIBRA, Fundação Joaquim Nabuco.

${ }^{54}$ Carta do Nordeste. Incendiários e bombeiros, op. cit.

${ }^{55}$ Carta do Nordeste. Incendiários e bombeiros, op. cit. 
Em março de 1984, o trabalho de desconstruir a memória pública de incendiário e subversivo ainda tomava os pensamentos e preocupaçôes de Francisco Julião. A campanha pró-Diretas lhe parecia favorável para instituir outros significados sobre o seu passado. Nesse momento, ele operacionalizava com a ideia de ruptura com o regime civil-militar e ao mesmo tempo com a destruição dos lugares de incendiário e subversivo definidos para ele por uma determinada leitura do passado.

No fragmento citado, o ex-líder camponês descreve um deslocamento que estaria ocorrendo no Brasil naqueles primeiros meses de 1984. Ele diz: "nós somos" — aqueles desejosos de restaurar a democracia e ocupantes das praças públicas para exigir eleiçóes diretas "hoje, os bombeiros do Brasil". E desejando reforçar, para quem duvidava, finaliza: "Sim, os bombeiros." Colocar-se nessa posição, "hoje", era admitir o deslocamento, partindo da posição na qual foi considerado incendiário. Era usar da memória do incendiário para se fazer ver a diferença, o percurso.

Ao escrever sobre os "incendiários do circo", Francisco Julião expressava a sua leitura de que caso as eleiçôes diretas não fossem restabelecidas em 1985, a populaçáo que estava nas ruas iria instaurar o caos, incendiar-se-ia. O fim da ditadura se daria pelas mobilizaçóes por eleiçóes diretas ou, em caso de derrota da emenda Dante de Oliveira, pelo levante social. E apesar de desejar desconstruir sua memória de incendiário, Julião usava uma estratégia semelhante à do início da década de 1960 . Em vez de reforma agrária na lei ou na marra daqueles anos, agora era Diretas já ou a revolta popular.

E assim demonstrava chegar a abril de 1984 confiante na ruptura e desprezando a conciliação. No dia 10, subiu ao palanque na Candelária, no Rio de Janeiro. Cerca de um milhão de pessoas estavam presentes. Até aquele momento era o maior comício da campanha das Diretas Já. Provavelmente havia sido convidado pelo governado Leonel Brizola, que cuidadosamente montou a lista de oradores, mobilizando a "tropa de choque do seu PDT" para ocupar náo só o palanque, mas também as primeiras fileiras da gigantesca plateia e assim distanciar ao máximo faixas e bandeiras do $\mathrm{PCdoB}$ e do $\mathrm{PT}{ }^{56} \mathrm{O}$ líder pedetista procurava afastar qualquer afronta mais direta ao governo militar.

Os discursos começaram por volta das 16 horas. O homenageado especial daquela tarde-noite era o advogado Sobral Pinto. Quando lhe foi concedida a palavra, ele tomou o microfone e com uma voz trêmula pediu silêncio: "Peço silêncio para falar. Quero falar à nação brasileira." A multidão o atendeu, diminuindo o barulho: "Este movimento não é contra ninguém. É a favor do povo. [...] Esse movimento, para produzir os efeitos que esperamos, é indispensável que se processe dentro da ordem das ideias, da ordem das aspiraçôes, da ordem pública." Os aplausos ecoaram pela lotada avenida Presidente Vargas. ${ }^{57}$

\footnotetext{
${ }^{56}$ Revista Veja, 18 de abril de 1984, p. 29.

${ }^{57}$ Revista Veja, op. cit. 
De acordo com Domingos Leonelli e Dante de Oliveira, autor da emenda para eleiçóes diretas, o discurso de Sobral Pinto era uma resposta a Francisco Julião, que momentos antes havia falado e atacado duramente os militares. O homenageado teria ficado tão irritado com essa postura que decidiu deixar o palanque. ${ }^{58}$ Foi impedido por Tancredo Neves, conhecido por suas atitudes conciliatórias, inclusive com os militares.

Francisco Juliáo e Sobral Pinto se conheciam desde os anos 1960. Este fora o advogado que defendeu e conseguiu um habeas corpus em 1965 para o ex-dirigente das Ligas Camponesas. Alguns meses antes daquele reencontro na Candelária, em novembro de 1983, Julião lhe havia escrito uma carta. Justificava-se pela ausência às comemoraçóes e homenagens aos seus 90 anos de vida e relembrava o encontro entre eles em uma das prisóes da ditadura.

Certa manhã, o imenso portão de ferro, capaz de deter a fúria de um elefante, abriu-se para dar passagem a sua figura frágil, vestida de negro, com seu impecável guarda-chuva [...] Percebi, desde o início do nosso diálogo, que o senhor viera tirar uma dúvida, antes de aceitar a minha causa. É que a imagem que o senhor tinha do seu constituinte encarcerado era, até aquele momento, a de um pirômano. Os discípulos do Dr. Göebels [...] transformaram o modesto defensor de camponês sem terra em incendiário de canaviais no Nordeste. ${ }^{59}$

Por que, nessa carta para justificar a sua ausência e desejar felicidades, Francisco Juliáo recuperou a memória do incendiário? Meses depois, na Carta do Nordeste de março de 1984, essa memória voltaria a ser utilizada, mesmo que para apresentar uma mudança de posição. Nesse momento, o "pirômano" era os militares e políticos que se contrapunham a aprovação das Diretas Já. E, nesse caso, Julião se diz o "bombeiro. Sim, o bombeiro".

A rememoração do passado, considerada por Beatriz Sarlo, "não é uma escolha, mas uma condição para o discurso, que não escapa da memória, nem pode livrar-se das premissas impostas pela atualidade à enunciaçáo" ${ }^{60}$ Recordar o encontro ocorrido na prisão em 1965 era uma forma de estabelecer uma aproximaçáo, um elo entre o destinatário e o remetente de 1983. Mas, isso não significava obrigatoriamente caminhar pela memória do incendiário. Essa opção diz do momento a partir do qual Francisco Juliáo lançava seu enunciado. A carta para Sobral Pinto, no final de 1983, bem como aquela intitulada Incendiários e bombeiros, em março do ano seguinte, indicavam a pulsante necessidade em ressignificar a leitura do seu passado.

Com efeito, essa insistência em utilizar as mesmas expressóes do passado demonstrava o quanto essas representaçôes que lhe eram atribuídas no tempo das Ligas Camponesas ainda estavam presentes na redemocratizaçáa do Brasil. O seu discurso considerado como um

\footnotetext{
${ }^{58}$ LEONELLI, Domingos; OLIVEIRA, Dante. Diretas Já: 15 meses que abalaram a ditadura, op. cit., p. 488. ${ }^{59}$ Carta de Francisco Julião a Sobral Pinto. Novembro de 1983. FJ CEP 1 doc 8 - C3. CEHIBRA, Fundação Joaquim Nabuco.

${ }^{60}$ SARLO, Beatriz. Tempo passado: cultura da memória e guinada subjetiva. São Paulo: Companhia das Letras; Belo Horizonte: UFMG, 2007, p. 49.
} 
ataque aos militares no comício da Candelária poderia ter relembrado para Sobral Pinto e outros presentes aquele personagem considerado incendiário do Nordeste do Brasil nos idos de 1960. Não se ateava mais fogo nos canaviais, mas se incendiaria a multidão assistente àquele comício por eleiçôes diretas. Daí a reação do advogado homenageado do evento.

O que Francisco Julião teria dito em seu discurso na Candelária? Na ausência de registros, pode-se recorrer à outra Carta do Nordeste, datada de abril de 1984, escrita depois do evento no Rio de Janeiro e intitulada Da Candelária a Cabrobó. É um texto manuscrito, ocupando cinco páginas, com várias passagens riscadas e reescritas. O primeiro parágrafo explicava o título: "Tivemos a fortuna de participar de dois grandes atos cívicos, o primeiro deles, no dia 10, no Rio, e o segundo, em Cabrobó, no Sertão de Pernambuco. Não existe distância entre o Rio e Cabrobó no que diz respeito às eleiçóes diretas”. ${ }^{61}$ Essas e outras cidades do país estariam unidas pelo desejo de mudança.

$\mathrm{O}$ entusiasmo dos escritos anteriores mantinha-se nessa carta. Considerava-se que na história do Brasil não havia existido nenhuma campanha que, sequer, atingisse "a metade ou um terço da que nos empolga agora". E completava: "Os deputados e senadores estão diante de um povo que se levantou e em gloriosa marcha percorre o país de um canto a outro". Caso esses congressistas aprovassem a emenda Dante de Oliveira, receberiam o respeito de 130 milhóes de brasileiros. Contudo, profetizava, "negar esse direito mais que legítimo de um povo que esperou mais de 20 anos por essa hora estelar de sua vida equivale a insultar a sua consciência cívica e provocar a sua ira. Não se sabe exatamente o que virá depois. Mas que virá, virá”. ${ }^{62}$

Imagine os termos dessa carta presentes no discurso realizado na Candelária. Haveria Francisco Julião afirmado que o povo se levantou e marchava pelo país? Teria dito que caso a eleição direta não fosse aprovada, se veria a ira do povo? Talvez consideraçóes como essas tenham provocado indignação não apenas em Sobral Pinto, mas em políticos presentes, como o deputado federal Miguel Arraes e o governador Tancredo Neves.

Até abril de 1984, em suas cartas, Francisco Julião defendia a possibilidade de ruptura com o regime militar. Seja por meio da aprovação da emenda Dante de Oliveira, seja pela reação popular impulsionada por uma derrota das Diretas Já no Congresso Nacional. Neste momento, negociação e conciliação não lhe pareciam posições corretas. E apesar do pouco espaço de ação política e das interdiçóes que o cerceavam, por ser nomeado de incendiário e radical, ele criava provocaçôes, testando modificaçóes para os limites da redemocratização no Brasil. ${ }^{63}$

\footnotetext{
${ }^{61}$ Carta do Nordeste. Da Candelária a Cabrobó. Abril de 1984. FJ PIp 4 doc 30,4. CEHIBRA, Fundação Joaquim Nabuco.

${ }^{62}$ Carta do Nordeste. Da Candelária a Cabrobó, op. cit.

${ }^{63}$ Nesse ponto, estou pensando a relação, de submissão e de inflecção, entre o ser falante e as formas de poder que o cercam. FARGE, Arlette. Lugares para a História. Belo Horizonte: Autêntica, 2011, p. 65.
} 


\section{A derrota das Diretas Já e as novas cartas}

A emenda Dante de Oliveira não passou na Câmara dos Deputados, como era previsto. Ao final da votação o placar marcava: 298 votos a favor da emenda, 65 contra, 3 abstençóes e 113 faltosos. Faltaram 22 votos para se alcançar os dois terços necessários a uma alteração constitucional por eleições diretas já.

O que se seguiu foi o fortalecimento da estratégia de negociação política para a sucessão presidencial por meio do Colégio Eleitoral. Tancredo Neves, que ganhou força com a campanha das Diretas Já, passou a simbolizar a opçáo mais confiável, principalmente para os setores militares.

Cada vez mais o governador mineiro projetava-se com a imagem de um homem público que esteve presente nos principais momentos da história nacional, pelo menos nos últimos trinta anos. Incluía-se também, nessa sua projeção, uma posição de combate à ditadura, apesar da sua atuação parlamentar muito discreta durante esse período e da sua participação na criação e liderança do efêmero Partido Progressista (PP), também conhecido como partido do Petrônio. ${ }^{64}$

Com a derrota das Diretas Já, a candidatura de Tancredo Neves atraiu os setores insatisfeitos com o governo. Havia uma movimentação no sentido de que sua campanha fosse entendida como uma continuidade do movimento popular, recorrendo, inclusive, ao uso das cores verde e amarelo e das expressōes Mudança Já e Tancredo Já. ${ }^{65}$ A eleição indireta de 1985 ganhou ares de plebiscito. Posicionava-se a favor ou contra os militares.

A grande exposição na mídia tornou o candidato do PMDB o primeiro presidente "televisual". ${ }^{66}$ Também contribuiu para a rápida institucionalização de sua imagem enquanto um resistente de primeira hora à ditadura, representante dos anseios de mudança da população e, depois de sua morte, um mártir da democracia brasileira.

A imagem de Tancredo Neves como um herói nacional sem vínculos com a ditadura e promotor da conciliação da naçáo era individual, mas, em determinado nível, era também social. Pois era o futuro presidente e amplas parcelas da sociedade que procuravam se identificar com essa imagem, como alerta Daniel Aarão ao analisar as ressignificaçôes, durante a redemocratização, da memória social sobre o período ditatorial: "a ditadura, quem apoiou? Muitos poucos, raríssimos, nela se reconhecem ou com ela desejam ainda se identificar. Ao contrário, como se viu, quase todos resistiram". ${ }^{67}$

\footnotetext{
${ }^{64}$ Era uma referência ao Ministro da Justiça de Figueiredo, Petrônio Portela, estrategista político que traçou os caminhos do PP como uma legenda auxiliar do PDS.

${ }^{65}$ MARCELINO, Douglas Attila. O corpo da Nova República: funerais de presidentes e memória de Tancredo Neves. Tese (Doutorado em História) — PPGHIS — Universidade Federal do Rio de Janeiro. 2011, p. 114. ${ }^{66}$ MARCELINO, Douglas Attila. O Corpo da Nova República: funerais de presidentes e memória de Tancredo Neves, op. cit.

${ }^{67}$ REIS, Daniel Aarão. Ditadura e sociedade: as reconstruçôes da memória. In: REIS, Daniel Aarão; RIDENTI, Marcelo (Orgs.). O golpe e a ditadura militar: 40 anos depois (1964-2004). Bauru, SP: Edusc, 2004, p. 50.
} 
Mesmo com a derrota no Congresso da emenda Dante de Oliveira-Diretas Já, considerada naquele momento como estratégia política fundamental para a ruptura com o regime militar, uma parcela considerável da sociedade, e mesmo aquela que colaborou com a ditadura, passa absolver-se e representar o Brasil "como uma nação democrática, reconciliando-se, reconciliada". ${ }^{68} \mathrm{E}$ dizer-se reconciliada era excluir os radicalismos, de direita e de esquerda. "Segurem os seus radicais que nós seguramos os nossos", ${ }^{69}$ já dizia um assessor do presidente Geisel no processo de distensão. "A saída para conflitos irreversíveis [acontecerá] se as forças que representam o poder e a sociedade civil souberem conter as suas posiçóes de radicalismo", declarava Tancredo Neves ao defender um entendimento com o PDS, em abril de $1984 .^{70}$

A crítica e os ataques, principalmente na imprensa, contra políticos e grupos representados e nomeados como radicais tornaram-se, depois da campanha por eleiçôes diretas, um dos pontos de convergência entre governo e setores da oposição no caminho para a conciliação e produção de uma nova democracia no Brasil. Entretanto, como diz Francisco Weffort, "em 1974, quando Geisel chegou à presidência, já não havia "radicais" nas oposições, pelo menos não no sentido que o regime atribui a esta palavra", ${ }^{71}$ Afinal, as guerrilhas haviam sido derrotadas, muitos militantes presos e assassinados e outro setor da esquerda caminhava para converter suas açôes unicamente em lutas pela democracia. Nesse ponto, governo e grupos de oposiçáo - parcelas do PMDB, do PDT e grupos da sociedade civil, por exemplo - passam a se aproximar. O primeiro ressaltando o quanto se caminhou, enquanto o segundo o quanto se faltava. Mas, o ponto final seria o mesmo; a democracia, conciliada e sem radicalismos.

A busca de negociação com o governo teria estado em risco em diversos momentos da campanha pelas Diretas Já, sobretudo, pela intensa e até inesperada mobilização popular. Entretanto, com a derrota da emenda Dante de Oliveira e a candidatura de Tancredo Neves a negociação foi restabelecida. E os radicais que eram representados pelo regime como derrotados voltaram a existir, no dispositivo da transição, como aqueles que poderiam ameaçar a conciliaçáo nacional. Passa a ser produzida e divulgada a necessidade de se combater os de esquerda para não haver uma reação dos da direita e vice-versa. Assim, à população que lotou as ruas, era recomendado que voltasse as suas casas.

E aqui peço licença ao leitor para trazer novamente o discurso de Sobral Pinto na Candelária, tomado como resposta a Francisco Julião. O advogado católico, que participou das

\footnotetext{
${ }^{68}$ REIS, Daniel Aarão. Ditadura e sociedade: as reconstruçôes da memória. In: REIS, Daniel Aarão; RIDENTI, Marcelo (Orgs.). O golpe e a ditadura militar: 40 anos depois (1964-2004), op. cit.

${ }^{69}$ WEFFORT, Francisco. Por que democracia? In: STEPAN, Alfred (Org.). Democratizando o Brasil. Rio de Janeiro: Paz e Terra, 1988, p. 511.

${ }^{70}$ CARVALHO, Alessandra. Do autoritarismo à democracia? Um estudo dos processos de transição no Brasil (1945 e 1984). Dissertação (Mestrado em História). PPGHIS — Universidade Federal do Rio de Janeiro, 2000, p. 128.

${ }^{71}$ WEFFORT, Francisco. Por que democracia? In: STEPAN, Alfred (Org.). Democratizando o Brasil, op. cit., p. $501-511$.
} 
Marchas da Família com Deus pela Liberdade logo após o Golpe civil-militar de 1964, ${ }^{72}$ grande homenageado daquele dia, teria pedido silêncio aos milhóes presentes. Parecia uma profecia, pois dias depois, passado o comício de São Paulo, as manifestaçôes foram se calando, substituídas mais tarde pelo choro e luto em razão da morte de Tancredo Neves. O discurso de Sobral Pinto anunciava uma proposta de funcionamento para as Diretas dentro de uma transição pactuada: "Este movimento não é contra ninguém. É a favor do povo. [...] Esse movimento, para produzir os efeitos que esperamos, é indispensável que se processe dentro da ordem das ideias, da ordem das aspirações, da ordem pública”. Sem radicalizaçôes, sem enfrentamentos, sem ruptura, pode-se complementar. ${ }^{73}$

Dias depois do comício da Candelária e da derrota da emenda Dante de Oliveira no Congresso Nacional, Francisco Julião escreveu uma nova Carta do Nordeste que se intitulava Sobre o radicalismo. Criticava o uso indiscriminado da palavra radicalismo como sinônimo de sectarismo.

A palavra radical incorporou-se ao dicionário político brasileiro com um significado equivalente ao termo sectário. Tornaram-se sinônimos. Os políticos falam em radicais de direita e radicais de esquerda, com a maior naturalidade, quando querem definir aqueles que se posicionam, de um lado ou de outro, como elementos antagônicos. A imprensa, por sua vez, endossa e divulga a palavra radical exatamente como ela existe e significa para o político. ${ }^{74}$

\footnotetext{
${ }^{72}$ LEONELLI, Domingos; OLIVEIRA, Dante. Diretas Já: 15 meses que abalaram a ditadura, op. cit., p. 488. ${ }^{73}$ As transições de regimes ditatoriais para democracias têm sido há algum tempo foco de estudo entre cientistas políticos e sociais. Ultimamente tem-se concluído que há uma diferença entre a transição e a consolidação democrática. São duas etapas distintas e o desenvolvimento da primeira não determina as características da segunda, nem mesmo se ela ocorrerá (MONCLAIRE, Stéphane. Democracia, transição e consolidação: precisóes sobre conceitos bestializados. In: Revista de Sociologia e Política. n. 17, p. 63, nov. 2001). Essa tese percorre unicamente o processo de transição, que atropelou o projeto de liberalizaçáo pensado no governo Geisel. O "processo" agregou forças diversas sociais, que lhe conferiram marchas e contramarchas, tentativas de ruptura e negociaçóes. O "projeto" apresentava uma autonomia pelo alto, bem mais restrita a setores do governo. Sobre essa discussão ver GLAUCIO, Ary Dillon Soares; D’ARAUJO, Maria Celina; CASTRO, Celso (Org.). A volta aos quartéis: a memória militar sobre a abertura. Rio de Janeiro: Relume Dumará, 1995, p. 38-40. Por fim, dentro da análise de transição, utiliza-se aqui dos termos propostos por Guilhermo O’Donell e operacionalizados por Francisco Teixeira em um dos melhores trabalhos historiográficos sobre a abertura política no Brasil: a transição pactuada, lenta e segura, resultante de acordo entre os que estáo no governo e as forças moderadas de oposição. Há uma ampla aceitação historiográfica de que esse foi o caso do Brasil. Outro tipo seria a transição por colapso, caracterizada pela ruptura com o autoritarismo vigente, como na Grécia e Argentina (SILVA, Francisco Carlos Teixeira da. Crise da ditadura militar e o processo de abertura política no Brasil, 1974-1985. In: DELGADO, Lucilia de Almeida Neves; FERREIRA, Jorge (Org.). O Brasil republicano. O tempo da ditadura militar: regime militar e movimentos sociais em fins do século XX. Vol. 4. Rio de Janeiro: Civilizaçâo Brasileira, 2009 e LINZ, Juan; STEPAN, Alfred. A transição e consolidação da democracia. Petrópolis: Paz e Terra, 1999).

${ }^{74}$ Carta do Nordeste. Sobre o radicalismo. 15 de maio de 1984. FJ PIp 5 doc 38,2. CEHIBRA, Fundaçáo Joaquim Nabuco.
} 
A leitura da carta permite-nos imaginar que o tema - do radical e do radicalismo - estava amplamente colocado no debate político. Os radicais já não existiam na oposição desde 1974, enquanto militantes armados prontos para uma ação, como indicava Weffort. No entanto, em meados da década de 1980, eram apresentados como os "elementos antagônicos" atuantes nos grupos de "direita" e de "esquerda". Muitos desses grupos haviam optado pela via conciliada e negociada da redemocratizaçáo, sentido reverberado pela imprensa.

Nesse cenário, Francisco Julião deveria ser nomeado como radical, por criticar os que se mostravam como moderados e promotores de uma conciliação sem a participação popular. Em maio de 1984 questionava a transiçáo conciliada comandada por setores do PMDB e do PDS:

[...] queremos [...] pedir aos nossos leitores que examinem, com isenção de ânimo, a questão aqui colocada, para que não caiam no jogo daqueles que, querendo passar por moderados, conciliadores ou consensuais, esquecem que a moderação, a conciliação e o consenso só valem se contarem com a participação do povo. ${ }^{75}$

Em nenhuma passagem da carta o ex-dirigente das Ligas Camponesas negava a sua condição de radical. Procurava, entretanto, desde o princípio, ressignificá-la, romper com o sentido único que os "conciliadores ou consensuais" conferiam à palavra. Aqui ele atuava como um Vitangelo Moscarda, o múltiplo personagem de Luigi Pirandello, para quem as palavras são vazias de sentido, mas quando ditas são preenchidas por quem as enuncia e as escuta. ${ }^{76} \mathrm{E}$ assim dizia Julião:

Radical é todo aquele que vai em busca de uma raiz. [...] O homem é a raiz de si mesmo, como dizia Marx. E, como a sociedade é composta de homens, no sentido genérico, as raízes de cada sociedade, de cada povo, são os próprios homens. [...] Todo homem, portanto, é um radical. E partindo desse raciocínio [...] distinguimos o radicalismo do sectarismo, do fanatismo, da ortodoxia, do facciocismo, expressōes comumente usadas como sinônimo de radicalismo. ${ }^{77}$

Criticava o uso que seus adversários faziam da palavra radical e a colocava como representante da essência social do homem. Isso romperia com o discurso de que existiria especi-

\footnotetext{
${ }^{75}$ Carta do Nordeste. Sobre o radicalismo, op. cit.

${ }^{76}$ Discussão de Luigi Pirandello sobre a produção de sentidos, por meio do seu personagem principal no romance Um, nenhum e cem mil. PIRANDELLO, Luigi. Um, nenhum e cem mil. São Paulo: Cosac Naify, 2012, p. 55. A relação entre linguagem e sujeito e a produção de significados é um debate também realizada por Michel Foucault em livros como As palavras e as coisas. Uma forma de operacionalização historiográfica dessa discussão pode ser encontrada no texto de Antonio Montenegro Rachar as palavras: uma história a contrapelo. MONTENEGRO, Antonio Torres. Rachar as palavras: uma história a contrapelo. In: História, metodologia, memória, op. cit., p. 21-47.

${ }_{77}$ Carta do Nordeste. Sobre o radicalismo, op. cit.
} 
ficamente um grupo radical de esquerda, que poderia ameaçar o processo de conciliação no Brasil. O radicalismo estava na sociedade, irradiado e manifestado, "com a participaçáo do povo, cuja maturidade para tomar as grandes decisóes históricas destinadas a salvar a Nação foi ampla e radicalmente (grifo no original) demonstrada através da memorável campanha pelas eleições diretas".

O significado do radical que se diferenciava de posiçôes extremadas, sectárias ou fanáticas foi também utilizado para atualizar o líder das Ligas Camponesas da década de 1960:

Vamos ser mais concretos ainda. Nós preconizamos, desde os tempos das Ligas Camponesas, uma reforma agrária radical (grifo no original) para o Brasil. E continuamos a defender a mesma posição, hoje. Por quê? Porque a raiz do problema está no latifúndio. ${ }^{78}$

Sendo radical "todo aquele que vai em busca de uma raiz", Francisco Juliáo se representava assim por combater o latifúndio, raiz do problema agrário. Partindo desses significados, produz uma continuidade entre o autor dos anos 1980 e aquele que gritou "reforma agrária radical", na lei ou na marra. Retomou o discurso do líder das Ligas Camponesas da década de 1960, inserindo-o nos debates da transição política do Brasil. Realizava uma aproximação com esta imagem. Porém, em outros momentos, como no final do exílio, em entrevistas para periódicos de grande circulação no Brasil, tentou apagar a memória das lutas por reforma agrária radical lideradas por ele.

Os deslocamentos eram em múltiplas direçôes. Diferenciava-se da lógica da transição, mas também em certo nível se aproximava.

Não há, por conseguinte, nem direita radical nem esquerda radical. O que há é a direita sectária, fanática, ortodoxa, facciosa, intolerante, intransigente, como existe a esquerda que se póe do outro lado, agitando as mesmas bandeiras. Mudam as cores dessas bandeiras [...], mas a essência é uma só. Se pudéssemos escolher na terra um lugar para juntar os ultra da direita e da esquerda, e deixá-los aí, acabariam entendendo-se. A espécie é a mesma. ${ }^{79}$

No mesmo texto em que criticava a conciliação sem a participação popular compartilhava da prática de combate aos excessos políticos e as violências de setores da direita e da esquerda. Esses eram os radicais para uns. Eram os sectários e fanáticos para Juliāo. Ao final, tentava ressignificar o lugar do radical, refazendo sua memória, mas não o abandonava.

\footnotetext{
${ }_{78}$ Carta do Nordeste. Sobre o radicalismo, op. cit.

${ }^{79}$ Carta do Nordeste. Sobre o radicalismo, op. cit. 


\section{Últimas consideraçóes}

No final da década de 1970 e início dos anos 1980, Francisco Julião buscou produzir uma releitura de sua memória de líder camponês do período pré-golpe de 1964. Esse objetivo estava presente nas suas entrevistas concedidas nesse período final de exílio. Procurou se desfazer da imagem de líder radical de esquerda, negando que havia ordenado invasóes de terras ou incêndio de canaviais. Afirmou para a revista Veja que náo reativaria as Ligas Camponesas. Tentou se inserir em um discurso de conciliação nacional, ressaltando que ao regressar do exílio não levantaria barricadas nas ruas.

Mas retornar ao Brasil significou enfrentar antigas lutas políticas atualizadas no processo de redemocratização. Havia uma disputa pelos significados de 1964 e nela Francisco Julião era acusado, por setores da esquerda e líderes sindicais, de ser culpado pelo golpe civil-militar, devido à agitação social e política promovida junto aos trabalhadores rurais. Algumas de suas açóes públicas, como o disco Juliāo, verso e viola, de 1981, foram censuradas e criticadas, pois poderiam reativar uma memória indesejada para o processo de transição política dos anos 1980.

Essa memória referia-se à mobilização de camponeses que marchavam sob o lema de "reforma agrária na lei ou na marra". O passado era lembrado como uma ameaça e a ação de Juliáo poderia reativá-lo. Contudo, em nenhum momento o anistiado político demonstrou uma intenção de reorganizar um movimento social no campo. Integrou-se ao Partido Democrático Trabalhista, atuando na sua direção e desenvolvendo um trabalho para fortalecer suas bases e estabelecer alianças políticas nas eleições de 1982 e 1986.

Ao mesmo tempo, procurava ressignificar as suas açôes da década de 1960. Desejou criar uma memória que estivesse de acordo com o dispositivo da redemocratização do Brasil, constituídas pelos discursos e práticas de conciliação e negociação. Entretanto, náo conseguiu desassociar sua imagem das representaçôes sobre o líder das Ligas Camponesas. Elas foram atualizadas durante diversos momentos da redemocratização. O lugar que restou para ele nesse processo foi o do radical que devia ser combatido e excluído. E assim ele o foi. Morreu pobre e esquecido em um autoexílio no México em 1999. A anistia e a redemocratização não funcionaram para todos.

\section{Referências bibliográficas}

ABREU E LIMA, Maria do Socorro de. Construindo o sindicalismo rural: Lutas, Partidos, Projetos. Recife: Ed. Universitária da UFPE, 2005.

AGUIAR, Cláudio. Francisco Julião, uma biografia: o homem e a política, as ligas camponesas e a reforma agrária, exílio e ocaso. 1. ed. Rio de Janeiro: Civilização Brasileira, 2014. 
CARVALHO, Alessandra. Do autoritarismo à democracia? Um estudo dos processos de transição no Brasil (1945 e 1984). Dissertação (Mestrado em História) - PPGHIS, Universidade Federal do Rio de Janeiro, 2000.

DELEUZE, Gilles. Proust e os signos. Rio de Janeiro: Forense Universitária, 2006.

DELGADO, Lucilia de Almeida Neves. Diretas Já: vozes das cidades. In: FERREIRA, Jorge; REIS, Daniel Aarão. Revolução e democracia (1964...). Rio de Janeiro: Civilização Brasileira, 2007.

FARGE, Arlette. Lugares para a História. Belo Horizonte: Autêntica, 2011.

FERREIRA, Jorge. João Goulart: uma biografia. Rio de Janeiro: Civilização Brasileira, 2011. GLAUCIO, Ary Dillon Soares; D’ARAUJO, Maria Celina; CASTRO, Celso (Org.). A volta aos quartéis: a memória militar sobre a abertura. Rio de Janeiro: Relume Dumará, 1995.

GOMES, Angela de Castro. Escrita de si, escrita da História: A título de prólogo. In:

(Org.). Escrita de si, escrita da História. Rio de Janeiro: FGV Editora, 2004.

GUIMARÃES NETO, Regina Beatriz. Cidades da mineração - memórias e práticas culturais. Mato Grosso na primeira metade do século XX. Cuiabá: Carlini \& Caniato: EdUFMT, 2006.

HALLBWACHS, Maurice. A memória coletiva. São Paulo: Vértice, 1990.

JULIÃO, Francisco. Cambão: a face oculta do Brasil. Recife: Bagaço, 2009.

KOTSCHO, Ricardo. Explode um novo Brasil. Diário da Campanha das Diretas. São Paulo: Brasiliense, 1984.

LEONELLI, Domingos; OLIVEIRA, Dante. Diretas Já: 15 meses que abalaram a ditadura. Rio de Janeiro: Record, 2004.

LINZ, Juan; STEPAN, Alfred. A transição e consolidação da democracia. Petrópolis: Paz e Terra, 1999.

MARCELINO, Douglas Attila. O corpo da Nova República: funerais de presidentes e memória de Tancredo Neves. Tese (Doutorado em História) - PPGHIS, Universidade Federal do Rio de Janeiro, 2011.

MONCLAIRE, Stéphane. Democracia, transição e consolidação: precisões sobre conceitos bestializados. Revista de Sociologia e Política, n. 17, nov. 2001.

MONTENEGRO, Antonio Torres. Ligas Camponesas e sindicatos rurais em tempo de revoluçáo. História, metodologia, memória. Sáo Paulo: Contexto, 2010.

MOTA, Carlos Guilherme; LOPEZ, Adriana. História de Brasil: una interpretación. 1. ed. Salamanca: Ediciones Universidad de Salamanca, 2009.

PEREIRA, Anthony W. O mito de Francisco Julião. Cadernos de Estudos Sociais, v. 7, n. 1.

Recife: Fundação Joaquim Nabuco. Janeiro/junho 1991. 
PIRANDELLO, Luigi. Um, nenhum e cem mil. São Paulo: Cosac Naify, 2012.

POLLAK, Michael. Memória e identidade social. Estudos Históricos, Rio de Janeiro, v. 5, n. 10, p. 200-212,1992.

PORFÍRIO, Pablo F. de A. Medo, comunismo e revolução. Pernambuco (1958-1964). Recife: Ed. da UFPE, 2009.

REIS, Daniel Aarão. Ditadura e sociedade: as reconstruções da memória. In: REIS, Daniel Aarão; RIDENTI, Marcelo (Orgs.). O golpe e a ditadura militar: 40 anos depois (19642004). Bauru, SP: Edusc, 2004.

RODRIGUES, Alberto Tosi. Diretas Já: o grito preso na garganta. São Paulo: Editora Fundaçáo Perseu Abramo, 2003.

ROLLEMBERG, Denise. O apoio de Cuba a luta armada no Brasil: o treinamento guerrilheiro. Rio de Janeiro: Mauad, 2001.

ROUQUIÉ, Alain. América Latina. Introducción al extremo occidente. México: Siglo Veintiuno, 1989.

SALES, Jean Rodrigues. A luta armada contra a ditadura militar: a esquerda brasileira e a influência da Revolução Cubana. São Paulo: Fundação Perseu Abramo, 2007.

SANTIAGO, Vandeck. Francisco Juliäo, as Ligas e o golpe militar de 64. Recife: Comunigraf, 2004. . Francisco Juliāo: luta, paixão e morte de um agitador. Coleção Perfil Parlamentar Século XX. Recife: Assembleia Legislativa do Estado de Pernambuco, 2001. SARLO, Beatriz. Tempo passado: cultura da memória e guinada subjetiva. São Paulo: Companhia das Letras; Belo Horizonte: UFMG, 2007.

SILVA, Francisco Carlos Teixeira da. Crise da ditadura militar e o processo de abertura política no Brasil, 1974-1985. In: DELGADO, Lucilia de Almeida Neves; FERREIRA, Jorge (Org.). O Brasil republicano. O tempo da ditadura militar: regime militar e movimentos sociais em fins do século XX. Vol. 4. Rio de Janeiro: Civilização Brasileira, 2009.

SKIDMORE, Thomas. Brasil: de Getúlio a Castelo. 1930-1940. 7. ed. Rio de Janeiro: Paz e Terra, 1982

WEFFORT, Francisco. Por que Democracia? In: STEPAN, Alfred (Org.). Democratizando o Brasil. Rio de Janeiro: Paz e Terra, 1988. 